\title{
Effects of Oxytocin Administration on Oxytocin Release and Milk Ejection
}

\author{
J. Mačuhová, ${ }^{1}$ V. Tančin, ${ }^{2}$ and R. M. Bruckmaier ${ }^{1}$ \\ ${ }^{1}$ Physiology Weihenstephan, \\ Technical University Munich, Weihenstephaner Berg 3, \\ D-85350 Freising, Germany \\ ${ }^{2}$ Research Institute of Animal Production, \\ Hlohovská 2, 94992 Nitra, Slovakia
}

\section{ABSTRACT}

In experiment I, the effect of i.m. oxytocin (OT) injection (50 IU) on OT blood pattern was tested. Blood samples from 6 cows were collected for $2 \mathrm{~h}$ after OT injection either with or without milking. To test the effect of i.m. OT injection (50 IU) on milk ejection efficiency, intramammary pressure (IMP) was measured in 13 cows (experiment II). Milk ejection was induced by manual teat stimulation. After IMP increased and reached a plateau, OT was injected. In experiment III, the effect of chronic OT treatment on mammary gland sensitivity and endogenous OT release was tested. For $19 \mathrm{~d}$, cows were i.m. injected at each milking with 50 IU OT $(\mathrm{n}=13)$ or $5 \mathrm{~mL}$ of $\mathrm{NaCl} 0.9 \%(\mathrm{n}=14) 1 \mathrm{~min}$ before the start of udder preparation. To test mammary gland sensitivity, IMP recording was performed after a long (11 h, 7 OT cows, and $7 \mathrm{NaCl}$ cows) and a short (3 h, 6 OT cows, and $7 \mathrm{NaCl}$ cows) milking interval at $\mathrm{d}-1$ and $\mathrm{d} 18$. To test the effect of withdrawal of chronic i.m. treatment on OT release, blood sample collection was performed during evening milking at $\mathrm{d} 0$ and $\mathrm{d} 19$. Intramuscular oxytocin injection (experiment I) caused elevated OT blood levels observed at least for $2 \mathrm{~h}$ and showed an even more pronounced effect when milking was also performed. Intramuscular OT injection after teat stimulation (experiment II) caused additional milk ejection but only in 6 out of 13 cows. Withdrawal of chronic OT treatment (experiment III) did not reduce OT release during milking. However, ejection time was prolonged during OT infusion after a long milking interval. Ejection pressure tended to be lower after a short milking interval. It seems that the reduction of spontaneous milk removal after chronic OT treatment was due to reduced contractibility of myoepithelial cells in the mammary gland at a physiological range of OT concentrations.

Received: June 18, 2003.

Accepted: October 14, 2003.

Corresponding author: R. M. Bruckmaier; e-mail: bruckmaier@ wzw.tum.de.
(Key words: oxytocin treatment, milk ejection, cow)

Abbreviation key: AUC = area under the curve, IMP = intramammary pressure, OT = oxytocin.

\section{INTRODUCTION}

Alveolar milk ( $\sim 80 \%$ of the total milk stored in the cow's udder) is fixed by adhesive and capillary forces and must be actively shifted into the cisternal cavity by the milk-ejection reflex to become available for removal (Knight et al., 1994; Pfeilsticker et al., 1995; Bruckmaier and Blum, 1998). Milk ejection is a neuroendocrine reflex; oxytocin (OT), released from the pituitary in response to tactile teat stimulation, causes myoepithelial cells surrounding the alveoli to contract, forcing milk stored in the alveoli into the mammary ducts and gland cistern (Lefcourt and Akers, 1983). However, not all the milk can be removed from the udder. Up to $90 \%$ of stored milk is removed from cows during normal machine milking through the action of endogenous OT (Knight, 1994; Bruckmaier, 2003). The remaining residual milk can be removed after i.v. administration of OT at supraphysiological dosage (10 IU) (Knight, 1994; Bruckmaier, 2003).

In dairy practice, exogenous OT is frequently administered to cows before milking to cure disturbed milk ejection caused by lacking or reduced OT release or for mastitis therapy. However, the effect of i.m. OT injection on OT blood pattern and milk ejection efficiency is unclear. Moreover, long-term OT treatment in cows reduces spontaneous milk ejection after withdrawal of OT (Donker et al., 1954; Bruckmaier, 2003). Two possible hypotheses were suggested. The first hypothesis was that chronic administration of exogenous OT reduces release of endogenous OT. The second hypothesis could be that chronic administered OT reduces sensitivity to OT in the udder, possibly due to an OT receptor down-regulation.

The objective of this study was to test the effect of chronic premilking i.m. OT treatment on endogenous OT release and on the sensitivity of the mammary gland 
to OT. Additionally, the effect of occasional i.m. OT treatment on the OT blood pattern and milk ejection efficiency was tested.

\section{MATERIALS AND METHODS}

\section{Animals}

A total of 13 primiparous and 23 multiparous Brown Swiss clinically healthy dairy cows were used for the experiments. They were in wk $34 \pm 4$ of lactation with a daily milk yield $24 \pm 1 \mathrm{~kg}$ at the start of the experiment. The cows were kept in loose housing and had free access to a mixed ration, providing energy and other nutrients for the production of $22 \mathrm{~kg}$ of milk/d. In addition, cows received concentrate from automatic feeders according to their individual production levels.

\section{Milking Routine}

Cows were routinely milked twice daily at 0500 and $0400 \mathrm{~h}$ in a $2 \times 2$ tandem milking parlor. Milking started after a short manual udder preparation (including forestripping and cleaning of the teats with wet towels) for 10 to $15 \mathrm{~s}$ and $1 \mathrm{~min}$ of vibration stimulation (Stimopuls, Westfalia Landtechnik GmbH, Oelde, Germany). After milk flow decreased to below $0.2 \mathrm{~kg} / \mathrm{min}$, machine stripping was performed. After stripping, cluster was manually removed. Milk yield was recorded at each milking via a strain gauge system, as described previously (Bruckmaier et al., 1992).

\section{Experimental Design}

Experiment I. The effect of occasional i.m. injection of $50 \mathrm{IU}$ of OT (Oxytocin-S, Intervet, GmbH, Tönisvorst, Germany) with or without simultaneous machine milking on OT blood levels was tested in 6 cows (3 primiparous and 3 multiparous). Cows were in wk $42 \pm 1$ of lactation with a daily milk yield of $18 \pm 2 \mathrm{~kg}$. Blood sample collection was performed at morning milking time during 3 subsequent days. On d 1, blood sample collection was performed (at 1-min intervals from $2 \mathrm{~min}$ before until 14 min after the start of milking) during milking without OT injection. On d 2, blood sample collection was performed after i.m. OT injection with milking and on $\mathrm{d} 3$ without milking ( $1 \mathrm{~h}$ after morning milking). Blood samples were taken at 1-min intervals from $1 \mathrm{~min}$ before until $15 \mathrm{~min}$ after OT injection, at 5-min intervals until $30 \mathrm{~min}$, at 10-min intervals until $60 \mathrm{~min}$, and in 15-min intervals until $120 \mathrm{~min}$ after OT injection similarly with or without milking. Milking was started at 1 min after i.m. OT injection.

Experiment II. To test the effect of occasional i.m. OT injection (50 IU) on milk ejection efficiency, intra- mammary pressure (IMP) was measured in 4 primiparous and 9 multiparous cows. They were in wk $39 \pm 5$ of lactation, with daily milk yield of $23 \pm 2 \mathrm{~kg}$. Intramammary pressure was measured at evening milking time in the parlor through a cannula inserted in the teat channel by using a strain gauge system, as previously described (Bruckmaier et al., 1994). Milk ejection was induced by manual teat stimulation. Manual teat stimulation lasted until IMP increased and plateau was reached. Afterward, OT was injected. Intramammary pressure recording lasted until IMP increased again and a new plateau was reached or for at least $6 \mathrm{~min}$ after OT injection. Variables evaluated were baseline pressure (pressure before start of teat stimulation), ejection pressure (pressure maximum in response to teat stimulation), induction time (time from start of teat stimulation until start of pressure increase), and ejection time (time from the start of teat stimulation until ejection pressure was reached). Moreover, IMP variables were also measured after the OT injection. Cows were milked immediately after the end of IMP recording.

Experiment III. The objective of this experiment was to test whether the reduced sensitivity of the mammary gland to OT or reduced release of OT from the pituitary are responsible for the reduced spontaneous milk ejection after chronic OT treatment. Ten primiparous and 17 multiparous cows were used for the experiment. Cows were in wk $32 \pm 5$ of lactation with a daily milk yield of $25 \pm 1 \mathrm{~kg}$. They were randomly assigned to 2 treatment groups and for an experimental period of $19 \mathrm{~d}$ (from a.m. milking on $\mathrm{d} 1$ to a.m. milking on $\mathrm{d}$ 19) they were i.m. injected at each milking with $5 \mathrm{~mL}$ (50 IU) of OT (OT group; 13 cows) or $5 \mathrm{~mL}$ of $\mathrm{NaCl} 0.9 \%$ ( $\mathrm{NaCl}$ group; 14 cows) 1 min before the start of udder preparation, which was done according to the regular milking routine. To detect changes of mammary gland sensitivity to OT as a consequence of a chronic OT treatment, the IMP in the udder cistern was recorded before $\mathrm{d}-1$ and on $\mathrm{d} 18$ of the experimental period. Cow groups were split at random into 2 subgroups in which IMP was recorded at 2 filling degrees of the udder. Differences in filling degree were produced by a long $(11 \mathrm{~h} ; 7$ OT cows and $7 \mathrm{NaCl}$ cows) or a short ( $3 \mathrm{~h} ; 6$ OT cows and $7 \mathrm{NaCl}$ cows) milking interval. The udder was emptied at the previous milking after machine stripping by remilking after an i.v. OT (1 IU). Intramammary pressure recording was performed in the stable (unusual surroundings for milking) to avoid spontaneous milk ejection. Milk ejection was induced by continuous OT infusion (0.15 IU/min infused by pump through a permanent catheter inserted into the jugular vein). A lag time of 2 min was applied after cannula insertion into the teat channel until the start of infusion to prove that sponta- 
neous milk ejection did not occur. Oxytocin infusion and IMP recording were prolonged until IMP maximum was reached. Variables evaluated were baseline pressure (pressure before start of OT infusion), ejection pressure (pressure maximum in response to OT infusion), induction time (time from start of OT infusion until start of pressure increase), and ejection time (time from start of OT infusion until ejection pressure was reached). To test the effect of the continuous OT infusion on OT blood plasma concentrations on d 20, additional catheters were inserted in the contralateral jugular vein of 5 animals, and blood sampling was performed. Blood samples were taken at 1-min intervals from -1 min until 10 min after the start of OT infusion.

On $\mathrm{d} 0$ and 19 of the experimental period, bloodsample collection was performed during milkings. At the morning milking, the effect of chronic premilking i.m. OT or $\mathrm{NaCl}$ treatment on OT blood pattern was studied. The effects of withdrawal of chronic OT or $\mathrm{NaCl}$ treatment on release of endogenous OT and spontaneous milk ejection were tested at the evening milking time when, at the end of milking (after stripping), 10 IU of OT were i.v. injected to obtain residual milk. Blood samples were collected at 1-min intervals from $1 \mathrm{~min}$ before the start of udder preparation until the end of milking (morning milkings) or until i.v. OT injection (evening milkings).

Additional measurement. Two days after withdrawal of chronic premilking i.m. OT treatment (experiment III), 10 IU of OT were injected i.v. after milking to 6 animals from the OT group to obtain residual milk and follow normalization of milk removal.

\section{Blood Sample Collection and OT Determination}

Blood samples $(10 \mathrm{~mL})$ were taken via a permanent catheter (Cavafix Cetro Splittocan 335, length $32 \mathrm{~cm}$, diameter $1.8 \times 2.35 \mathrm{~mm}$, Braun, Melsungen, Germany) inserted in a jugular vein $1 \mathrm{~d}$ before experiments. Blood samples were anticoagulated with EDTA, cooled on ice, centrifuged at $1500 \times g$ for $15 \mathrm{~min}$, and the plasma was stored at $-20^{\circ} \mathrm{C}$ until plasma OT concentration was determined by radioimmunoassay (Schams, 1983).

\section{Mathematical and Statistical Evaluations}

For statistical analysis of OT concentrations during milkings at $d 0$ and at $d 19$, mean values for -1 min, 0 min (start of udder preparation), for the period first to fifth minute of milking (area under curves $[\mathbf{A U C}] / \mathrm{min}$ 1 to $5 \mathrm{~min}$ ), for the last $2 \mathrm{~min}$ of milking (AUC/min last $2 \mathrm{~min}$ ), and for the entire milking (AUC/min entire milking) were calculated. When cows were i.v. injected with OT (10 IU), milk yields during these milkings

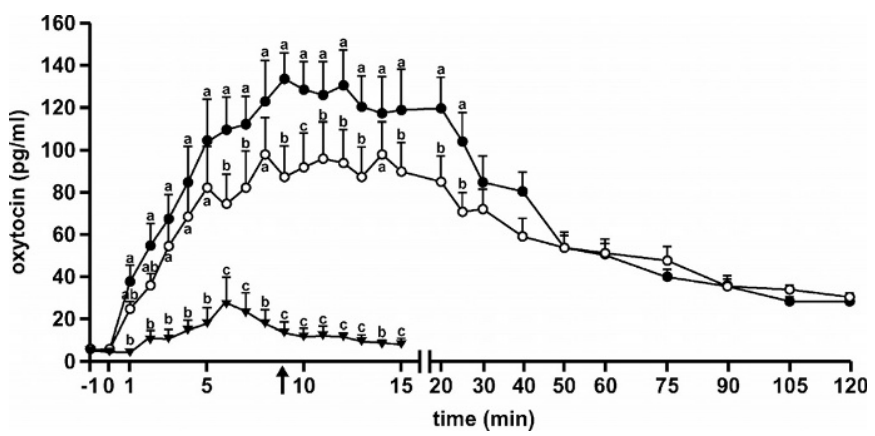

Figure 1. Oxytocin blood patterns in response to milking $(\boldsymbol{\nabla})$ and in response to i.m. oxytocin injection with milking $(\bullet)$ and without milking $(\bigcirc)$. Values are means \pm SEM for $\mathrm{n}=6.0=$ i.m. oxytocin injection; 1 = start of milking; $\uparrow$ the end of milking. The means within the same time without common superscript are significantly different $(P<0.05)$.

before and after the treatment period were divided into 2 fractions: milk obtained before OT treatment (spontaneously removed milk) and milk yield obtained in response to OT treatment (residual milk). For statistical analysis, a repeated measures analysis of variance was done using the MIXED procedure of the SAS program package (SAS Institute, 1999). In experiments I and III, the cow was the repeated subject. Significant differences $(P<0.05)$ between treatments and between treatment periods were localized by using Bonferroni's $t$-test based on least square means.

\section{RESULTS}

\section{Experiment I}

Oxytocin blood pattern in response to i.m. OT injection. Oxytocin blood patterns during milking without previous OT injection and in response to i.m. OT injection, with or without simultaneous milking, are shown in Figure 1. During milking without OT injection, OT levels increased in response to the milking stimulus. Toward the end of milking and after cluster removal, OT decreased and, a few minutes after milking, OT levels were only slightly elevated beyond basal level. Due to i.m. OT injection, levels of OT were already in the upper physiological range within a few minutes after injection. Simultaneous milking caused higher OT release. Milking time was similar with or without OT injection (7.8 $\pm 0.8 \mathrm{~min}$ and $7.9 \pm 0.5 \mathrm{~min}$, respectively). However, higher OT blood levels in response to i.m. OT injection with simultaneous milking were observed until $25 \mathrm{~min}$ (numerically until $50 \mathrm{~min}$ ) after i.m. OT injection. From 50 min after i.m. OT injection, the OT blood pattern followed a similar shape in both treatments. However, even $2 \mathrm{~h}$ after OT injection, OT levels were still above basal levels. 


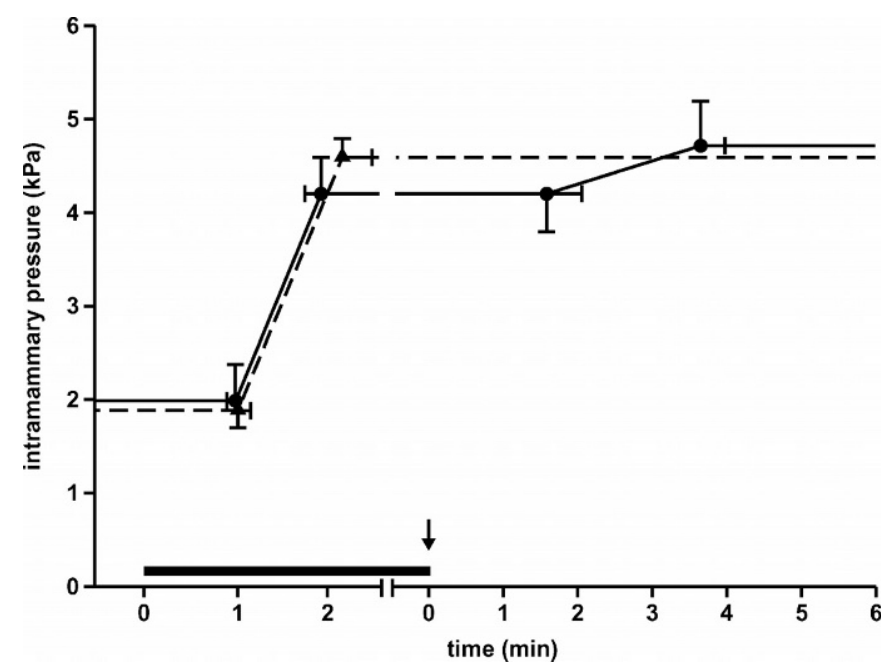

Figure 2. Intramammary pressure in response to manual teat stimulation and additional i.m. oxytocin injection (50 IU) in cows reacting ( ; solid line; $\mathrm{n}=7$ ), and in cows not reacting ( $\mathbf{\Delta}$; dash line; $\mathrm{n}=6$ ), to oxytocin injection. - manual teat stimulation; $\downarrow$ i.m. oxytocin injection (50 IU).

\section{Experiment II}

Milk ejection in response to i.m. OT injection. Results of IMP measurement in response to manual teat stimulation and to i.m. OT injection are shown in Figure 2. Cows reacted differently to i.m. OT injection. In 6 cows, no reaction was observed. Additionally, increased IMP in response to i.m. OT injection was observed in 7 cows. The amount of residual milk in cows not reacting and reacting to i.m. OT injection was similar $(15.3 \pm 3.0 \% ; 1.8 \pm 0.3 \mathrm{~kg} ; 13.0 \pm 2.7 \% ; 1.4 \pm 0.3$ $\mathrm{kg}$, respectively).

\section{Experiment III}

Milk removal in response to chronic premilking i.m. treatment. Chronic premilking i.m. $\mathrm{NaCl}$ or OT treatment did not significantly influence milk production. Milk yields before and during the treatment period did not differ in both groups $(P=0.87$ in the $\mathrm{NaCl}$ group, $P=0.07$ in the OT group). The equation of regression for milk yield was $\mathrm{y}=25.64-0.02 \times\left(\mathrm{R}^{2}=0.02\right)$ for $8 \mathrm{~d}$ before and $\mathrm{y}=25.49-0.03 \times\left(\mathrm{R}^{2}=0.08\right)$ during $16 \mathrm{~d}$ of chronic premilking $\mathrm{NaCl}$ treatment. In the OT group, the equation was $\mathrm{y}=24.86-0.09 \times\left(\mathrm{R}^{2}=0.49\right)$ for $8 \mathrm{~d}$ before and $\mathrm{y}=24.64+0.02 \times\left(\mathrm{R}^{2}=0.03\right)$ during $16 \mathrm{~d}$ of chronic premilking OT treatment.

Milk removal after withdrawal of chronic premilking i.m. treatment. Total milk yield did not differ before and after the treatment period in the $\mathrm{NaCl}$ group and was lower in the OT group (Table 1). Spontaneously removed milk and residual milk did not differ before and after the treatment period in the $\mathrm{NaCl}$ group. Withdrawal of chronic OT treatment caused a significant decline of spontaneously removed milk, whereas the amount of residual milk increased.

Mammary gland sensitivity in response to chronic premilking i.m. treatment. No differences in IMP patterns in response to continuous OT infusion after long ( $11 \mathrm{~h})$ and also after short $(3 \mathrm{~h})$ milking intervals were observed in the $\mathrm{NaCl}$ group at $\mathrm{d}-1$ and on $\mathrm{d}$ 18 of chronic premilking $\mathrm{NaCl}$ treatment (Figures 3 and 5). Chronic premilking OT treatment (Figure 4) caused a prolonged ejection time in response to continuous OT infusion measured after a long milking interval $(11 \mathrm{~h})$, whereas the other IMP traits did not change. During IMP measurement after a short milking interval $(3 \mathrm{~h})$ in the OT group performed on d 18 of chronic OT treatment, basal level increased and induction time was prolonged (Figure 6). Ejection time did not differ at $d-1$ and on $d 18$ of chronic OT treatment. Ejection pressure tended to be lower after, rather than before, chronic OT treatment $(P<0.1)$.

Oxytocin levels in response to continuous OT infusion (0.15 IU/min) during IMP recording are shown in Figure 7. Before the start of OT infusion, OT levels were low. Oxytocin concentration continuously increased until the end of infusion. During IMP recording, ejection pressure was reached within $4 \mathrm{~min}$. At this time, similar levels of OT were measured during milkings without premilking i.m. treatment (Tables 2 and 3).

Oxytocin release in response to chronic premilking i.m. treatment. Chronic premilking i.m. $\mathrm{NaCl}$ treatment had no effect on milking-related OT release (Table 2). Baseline OT concentrations were low until the start of premilking udder preparation. Oxytocin levels increased only in response to teat stimulation and remained elevated throughout the entire milking. Chronic premilking i.m. OT treatment caused OT levels to increase only $1 \mathrm{~min}$ after OT injection (before the start of the udder premilking preparation) (Table 1). Oxytocin levels steadily increased until the end of milking (AUC/min last $2 \mathrm{~min}>\mathrm{AUC} / \mathrm{min}$ entire milking). Oxytocin levels during milkings after chronic premilking i.m. OT treatment were significantly higher as during milking without i.m. OT treatment.

Oxytocin release after withdrawal of chronic premilking i.m. treatment. Oxytocin plasma concentrations during milkings before and after withdrawal of chronic i.m. treatment did not differ in both treatment groups (Table 3).

Normalization of milk removal after withdrawal of chronic OT treatment. Two days after withdrawal of chronic OT treatment, the amount of 
Table 1. Total milk yield and milk fractions during evening milking on d 0 and d 19 of the treatment period, i.e., last milking before and first milking after chronic i.m. treatment (experiment III). ${ }^{1}$

\begin{tabular}{|c|c|c|c|c|c|c|c|c|}
\hline \multirow{3}{*}{$\begin{array}{l}\text { Experimental day } \\
\text { Parameter }\end{array}$} & \multicolumn{4}{|c|}{$\mathrm{NaCl}$ group } & \multicolumn{4}{|c|}{ Oxytocin group } \\
\hline & \multicolumn{2}{|c|}{$\begin{array}{c}\mathrm{d} 0 \\
(\mathrm{n}=14)\end{array}$} & \multicolumn{2}{|c|}{$\begin{array}{c}\mathrm{d} 19 \\
(\mathrm{n}=14)\end{array}$} & \multicolumn{2}{|c|}{$\begin{array}{c}\mathrm{d} 0 \\
(\mathrm{n}=13)\end{array}$} & \multicolumn{2}{|c|}{$\begin{array}{c}\mathrm{d} 19 \\
(\mathrm{n}=13)\end{array}$} \\
\hline & Mean & SEM & Mean & SEM & Mean & SEM & Mean & SEM \\
\hline Total milk yie & 12.54 & 0.96 & 13.16 & 1.13 & 12.60 & 0.60 & $11.50 *$ & 0.57 \\
\hline Spontaneously removed milk, kg & 11.11 & 0.88 & 11.45 & 0.91 & 11.02 & 0.63 & $8.42^{* * * *}$ & 0.70 \\
\hline Spontaneously removed milk, \% & 88.94 & 1.99 & 88.98 & 1.60 & 87.47 & 2.42 & $72.88^{* * *}$ & 4.27 \\
\hline Residual milk, kg & 1.43 & 0.30 & 1.71 & 0.35 & 1.58 & 0.31 & $3.08 * * *$ & 0.47 \\
\hline Residual milk, \% & 11.06 & 1.99 & 12.02 & 1.58 & 12.53 & 2.42 & $27.12^{* * *}$ & 4.27 \\
\hline
\end{tabular}

${ }^{1}$ The means of measured parameters before and after did not differ in the $\mathrm{NaCl}$ group. Means in the oxytocin group on $d 19$ were significantly different from the means on $\mathrm{d} 0(* P<0.05 ; * * * P<0.0001)$.

residual milk was similar to amounts before the treatment period (Table 4). Therefore, milk removal at milking $1 \mathrm{~d}$ after withdrawal of OT treatment was also tested. Already at this milking, spontaneous milk removal did not differ from the pretreatment values.

\section{DISCUSSION}

It was suggested that a slow, constant absorption of OT into the bloodstream is taking place after s.c. OT treatment (Anderson et al., 1968). In response to i.m. OT injection (50 IU), OT levels had already increased within 1 min of administration. Within a few minutes, OT blood levels reached the upper physiological range. Higher OT levels were observed when milking was performed simultaneously. Interestingly, these higher lev-

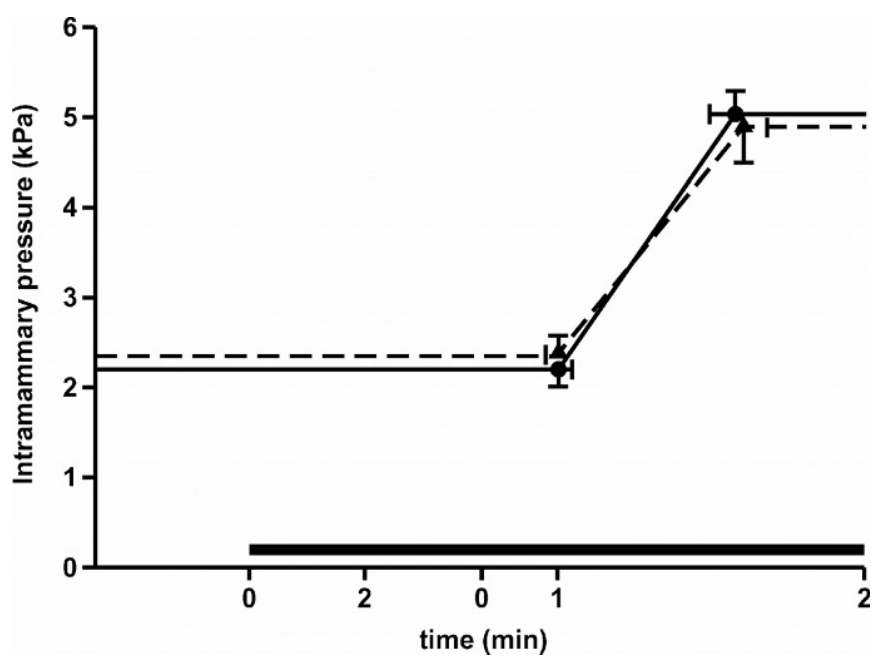

Figure 3. Intramammary pressure in the $\mathrm{NaCl}$ group before ( solid line) and on 18 of chronic premilking i.m. NaCl treatment ( $\mathbf{\Delta}$; dash line) in response to continuous oxytocin infusion ( $0.15 \mathrm{IU} / \mathrm{min})$ after long $(11 \mathrm{~h})$ milking interval. Values are means \pm SEM for $\mathrm{n}=$ 7. No significant differences in recorded parameters were observed. continuous oxytocin infusion. els in response to premilking i.m. OT injection were maintained until $50 \mathrm{~min}$ after OT injection, i.e., for a considerably longer time than the end of milking. Premilking i.m. OT injection had apparently no negative effect on the release of endogenous OT. It seems rather that i.m. OT injection potentiated the release of endogenous OT. Possibly, exogenous OT could act within the central nervous system, since 1 to $2 \%$ of doses given i.v. are supposed to pass through the bloodbrain barrier (Jones and Robinsson, 1982). From 50 min after i.m. OT injection with or without milking, OT blood patterns followed a similar shape. It seems that there was no more endogenous OT released, and OT blood levels were influenced only by resorption of i.m. injected OT. Two hours after injection, OT levels

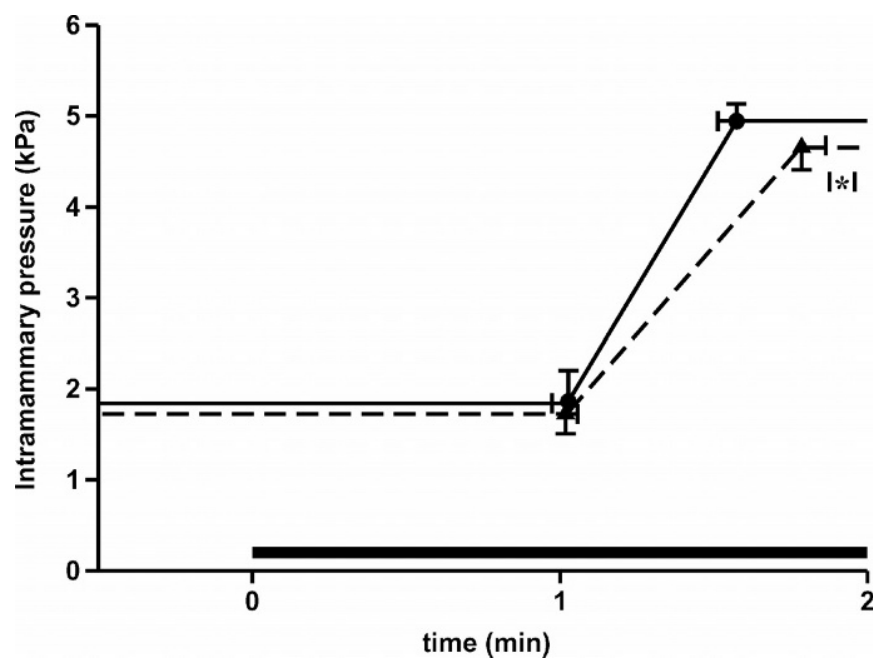

Figure 4. Intramammary pressure in the oxytocin group before (-; solid line) and on d 18 of chronic premilking i.m. oxytocin treatment ( $\mathbf{\Delta}$; dash line) in response to continuous oxytocin infusion $(0.15$ $\mathrm{IU} / \mathrm{min}$ ) after long $(11 \mathrm{~h})$ milking interval. Values are means \pm SEM for $n=7$. The mean on $d 18$ of the treatment period was significantly different from the mean before the treatment period $(P<0.05)$. continuous oxytocin infusion. 


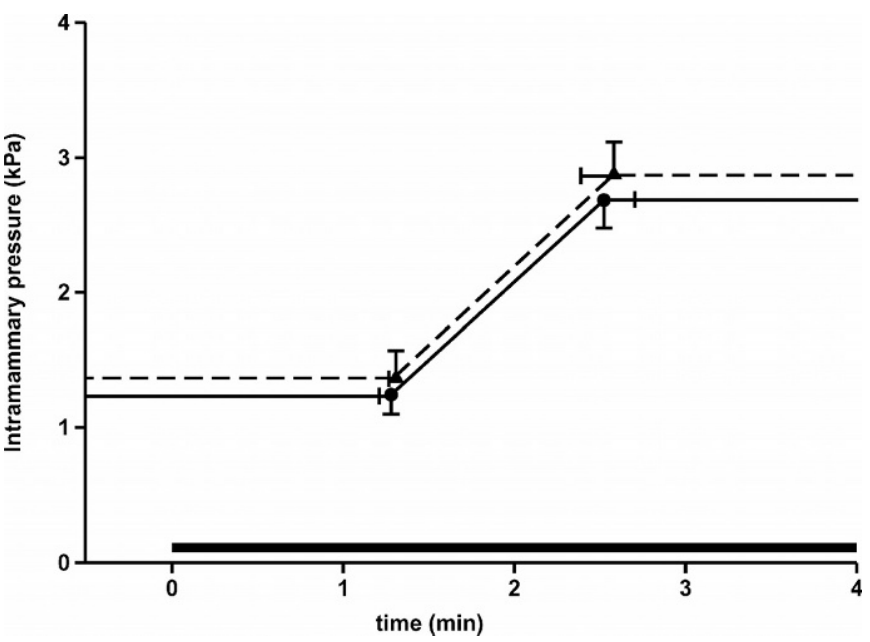

Figure 5. Intramammary pressure in the $\mathrm{NaCl}$ group before ( solid line) and on d 18 of chronic premilking i.m. NaCl treatment ( $\boldsymbol{\Delta}$; dash line) in response to continuous oxytocin infusion $(0.15 \mathrm{IU} / \mathrm{min})$ measured after short $(3 \mathrm{~h}$ ) milking interval. Values are means $\pm \mathrm{SEM}$ for $\mathrm{n}=7$. No significant differences in recorded parameters were observed. - continuous oxytocin infusion.

were still elevated beyond basal levels. Even chronic i.m. OT treatment did not reduce OT release during milking.

Oxytocin treatment had no effect (Bruckmaier, 2003), or rather stimulatory effect, on the milk yield in dairy cows (Nostrand et al., 1991; Ballou et al., 1993; Knight, 1994). Several mechanisms have been proposed to ex-

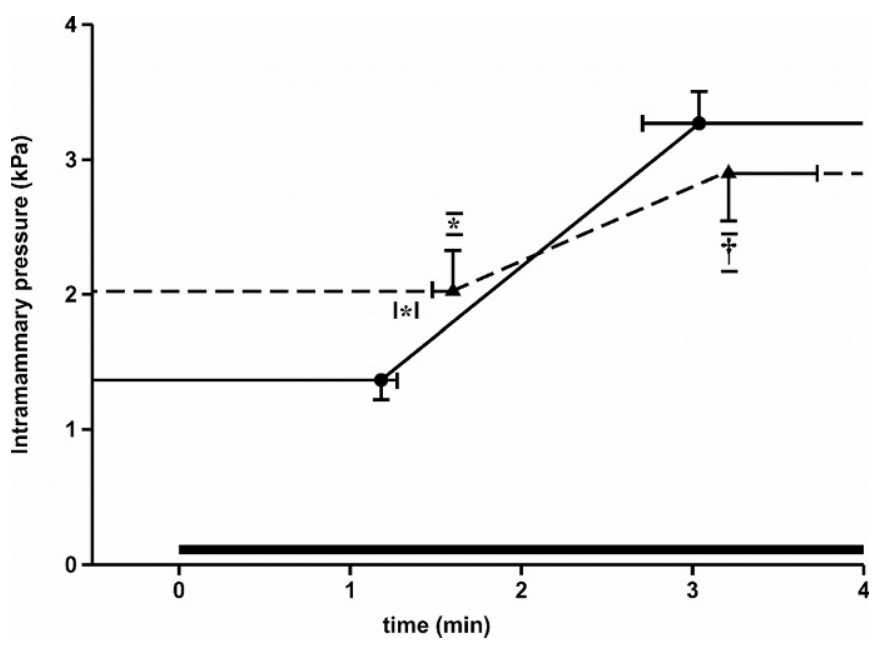

Figure 6. Intramammary pressure in the oxytocin group before (๑) solid line) and on d 18 of chronic premilking i.m. oxytocin treatment ( $\mathbf{\Lambda}$; dash line) in response to continuous oxytocin infusion $(0.15$ $\mathrm{IU} / \mathrm{min}$ ) measured after short ( $3 \mathrm{~h}$ ) milking interval. Values are means \pm SEM for $n=6$. The means on $d 18$ of the treatment period were significantly different $(* P<0.05)$ or tended to be different $(\dagger P<0.1)$ from the means before treatment period. - continuous oxytocin infusion.

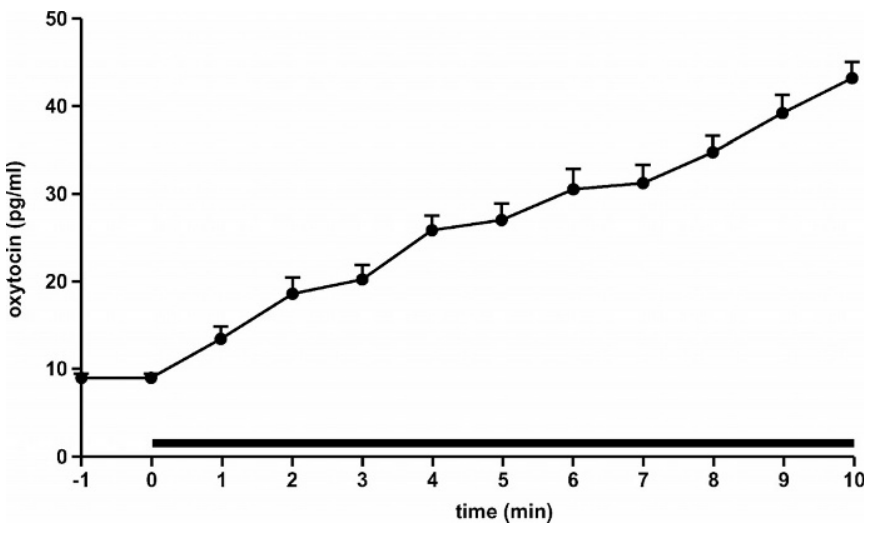

Figure 7. Oxytocin concentrations (pg/ml) in response to continuous oxytocin infusion $(0.15 \mathrm{IU} / \mathrm{min})$. Values are means \pm SEM for $\mathrm{n}=$ 5. - continuous oxytocin infusion.

plain the effect of OT administration on milk yield. One possibility is that OT may directly affect productivity or maintenance of mammary epithelial cells (Ballou et al., 1993; Lollivier et al., 2001). However, a previous study indicated that the galactopoietic effect of OT is due to increased efficiency of milk removal (Knight, 1994). High OT blood levels in response to premilking i.m. OT treatment could cause additional myoepithelial contraction toward the end of milking. Therefore, we could expect that the cows with higher residual milk to react much more to OT injection. However, the animals reacting to additional OT treatment with additional milk release had similar (even numerically lower) amounts of residual milk during milking compared with animals not reacting. Milk remained in the udder after i.m. OT injection (50 IU), which was removed after i.v. injection of 10 IU (Bruckmaier, 2003). Surprisingly, basal IMP levels, measured in the udder cistern $3 \mathrm{~h}$ after milking and with i.m. OT treatment, were significantly higher as before the treatment period. Milkings before IMP recording cows were i.v. treated with $1 \mathrm{IU}$ $\mathrm{OT}$ at the end of milking. Each time, the cows reacted to this treatment; therefore, the udders should be similarly emptied. It was suggested that the myoepithelial cells around the alveoli are not readily fatigued but respond to OT for a long time (Anderson et al., 1968). Oxytocin profiles after milking with premilking i.m. OT treatment showed that absorption of OT from muscle is a slow and continuous process. Elevated OT levels due to i.m. OT treatment caused prolonged contraction of myoepithelial cells. Considering that milk production is a continuous process, part of the residual milk and the newly secreted milk could descend into the udder cistern in shorter time than after control milking, and, consequently, the cisternal compartment was fuller. Therefore, it seems that at least part of the increase of 
Table 2. Oxytocin concentrations (pg/ml) during morning milking on d 0 (before treatment) and 19 of chronic premilking $\mathrm{NaCl}$ or oxytocin treatment (experiment III). ${ }^{1}$

\begin{tabular}{|c|c|c|c|c|c|c|c|c|}
\hline \multirow{3}{*}{ Experimental day } & \multicolumn{4}{|c|}{$\mathrm{NaCl}$ group } & \multicolumn{4}{|c|}{ Oxytocin group } \\
\hline & \multicolumn{2}{|c|}{$\begin{array}{c}\mathrm{d} 0 \\
(\mathrm{n}=14)\end{array}$} & \multicolumn{2}{|c|}{$\begin{array}{c}\mathrm{d} 19 \\
(\mathrm{n}=14)\end{array}$} & \multicolumn{2}{|c|}{$\begin{array}{c}\mathrm{d} 0 \\
(\mathrm{n}=13)\end{array}$} & \multicolumn{2}{|c|}{$\begin{array}{c}\mathrm{d} 19 \\
(\mathrm{n}=13)\end{array}$} \\
\hline & Mean & SEM & Mean & SEM & Mean & SEM & Mean & SEM \\
\hline \multicolumn{9}{|l|}{ Before milking } \\
\hline$-1 \min$ & $4.0^{\mathrm{aA}}$ & 0.3 & $4.8^{\mathrm{abA}}$ & 0.8 & $3.4^{\mathrm{aA}}$ & 0.2 & $5.1^{\mathrm{bA}}$ & 0.6 \\
\hline $0 \mathrm{~min}$ & $3.3^{\mathrm{aA}}$ & 0.4 & $6.4^{\mathrm{aA}}$ & 1.6 & $3.5^{\mathrm{aA}}$ & 0.3 & $13.7^{\mathrm{bA}}$ & 2.4 \\
\hline \multicolumn{9}{|l|}{ During milking } \\
\hline AUC/min $1-5$ min & $22.3^{\mathrm{aB}}$ & 4.2 & $26.5^{\mathrm{aB}}$ & 7.5 & $31.1^{\mathrm{aB}}$ & 14.7 & $79.4^{\mathrm{bB}}$ & 9.1 \\
\hline AUC/min last 2 min & $23.8^{\mathrm{aB}}$ & 5.0 & $33.3^{\mathrm{aB}}$ & 6.5 & $26.2^{\mathrm{aB}}$ & 8.6 & $115.2^{\mathrm{bC}}$ & 11.8 \\
\hline AUC/min entire milking & $24.0^{\mathrm{aB}}$ & 4.4 & $30.4^{\mathrm{aB}}$ & 7.3 & $30.3^{\mathrm{aB}}$ & 13.3 & $97.7^{\mathrm{bBC}}$ & 10.9 \\
\hline
\end{tabular}

${ }^{\mathrm{a}, \mathrm{b}}$ Means in the same line without a common superscript letter were significantly different $(P<0.05)$.

${ }_{\mathrm{A}, \mathrm{B}, \mathrm{C}}$ Means in the same column without a common superscript letter were significantly different $(P<0.05)$.

${ }^{1-1}=$ Intramuscular $\mathrm{NaCl}$ or oxytocin treatment during milkings on d 19.

$0=$ Start of udder preparation .

milk production in response to OT treatment is due to the kinetic role of OT, and that the removal of the residual milk at milking and the ejection of newly secreted milk from the alveoli into the cistern has a beneficial effect on subsequent secretion (Morag, 1967).

Chronic OT and $\mathrm{NaCl}$ treatment did not significantly influence milk production during the treatment period in this study. Lower total milk yield in the OT group during the first milking after the treatment period was caused not only by OT treatment during previous milking but, for unknown reasons, 2 animals had a reduced milk yield on this day. Whereas withdrawal of $\mathrm{NaCl}$ treatment had no effect on spontaneous milk removal, withdrawal of chronic premilking OT administration reduced spontaneous milk ejection, as previously observed (Bruckmaier, 2003). Also in this study, high individual variability was observed among cows. Whereas in some cows the amount of spontaneously removed milk did not differ, in other cows it was reduced by up to $36 \%$. Repeated OT injections have been shown to influence blood pressure (Petersson et al., 1996). However, some differences were observed between the effects of OT on female and male rats. This variation in blood pressure was related to the occurrence of the estrous cycle in females (Petersson et al., 1996). Cows used in our study were in different stages of their reproductive cycles. Possibly, steroid hormones could modulate the effect of chronic OT treatment.

High OT doses blocked milk ejection in lactating rats 90 min before the suckling period (Deis, 1971). Just a small dose of OT injected immediately before nursing induced a normal milk ejection, indicating that the blocking effect was not due to a lack of mammary gland response. It was suggested that OT could play a role in the regulation of its own release in the lactating rat. However, OT administration for a longer period did not influence the release of endogenous OT in dairy cows. The measured OT levels observed during first milking

Table 3. Oxytocin concentrations ( $\mathrm{pg} / \mathrm{ml})$ during evening milking on $\mathrm{d} 0$ and 19 of the treatment period, i.e., last milking before and first milking after chronic i.m. treatment (experiment III). ${ }^{1}$

\begin{tabular}{|c|c|c|c|c|c|c|c|c|}
\hline \multirow{3}{*}{ Experimental day } & \multicolumn{4}{|c|}{$\mathrm{NaCl}$ group } & \multicolumn{4}{|c|}{ Oxytocin group } \\
\hline & \multicolumn{2}{|c|}{$\begin{array}{c}\mathrm{d} 0 \\
(\mathrm{n}=14)\end{array}$} & \multicolumn{2}{|c|}{$\begin{array}{c}\mathrm{d} 19 \\
(\mathrm{n}=14)\end{array}$} & \multicolumn{2}{|c|}{$\begin{array}{c}\mathrm{d} 0 \\
(\mathrm{n}=13)\end{array}$} & \multicolumn{2}{|c|}{$\begin{array}{c}\mathrm{d} 19 \\
(\mathrm{n}=13)\end{array}$} \\
\hline & Mean & SEM & Mean & SEM & Mean & SEM & Mean & SEM \\
\hline \multicolumn{9}{|l|}{ Before milking } \\
\hline$-1 \min$ & $3.7^{\mathrm{A}}$ & 0.4 & $4.5^{\mathrm{A}}$ & 0.5 & $3.5^{\mathrm{A}}$ & 0.4 & $3.5^{\mathrm{A}}$ & 0.4 \\
\hline $0 \mathrm{~min}$ & $3.4^{\mathrm{A}}$ & 0.5 & $4.4^{\mathrm{A}}$ & 0.6 & $4.4^{\mathrm{A}}$ & 0.5 & $3.6^{\mathrm{A}}$ & 0.4 \\
\hline \multicolumn{9}{|l|}{ During milking } \\
\hline $\mathrm{AUC} / \mathrm{min} 1-5 \mathrm{~min}$ & $25.7^{\mathrm{B}}$ & 7.1 & $24.3^{\mathrm{B}}$ & 4.7 & $23.6^{\mathrm{B}}$ & 5.7 & $23.0^{\mathrm{B}}$ & 6.5 \\
\hline AUC/min last 2 min & $36.1^{\mathrm{B}}$ & 12.0 & $31.4^{\mathrm{B}}$ & 5.6 & $34.4^{\mathrm{C}}$ & 7.9 & $27.7^{\mathrm{B}}$ & 6.9 \\
\hline AUC/min entire milking & $27.7^{\mathrm{B}}$ & 7.0 & $26.8^{\mathrm{B}}$ & 4.7 & $27.1^{\mathrm{BC}}$ & 6.7 & $24.4^{\mathrm{B}}$ & 6.6 \\
\hline
\end{tabular}

${ }^{\mathrm{A}, \mathrm{B}, \mathrm{C}}$ Means in the same column without a common superscript letter were significantly different $(P<0.05)$.

${ }^{1}$ No significant differences in oxytocin release during milking were observed between groups before and after the treatment period. $0=$ Start of udder preparation. 
Table 4. Total milk yield and milk fractions during evening milking on $\mathrm{d} 0$ and 19 of the treatment period and $2 \mathrm{~d}$ after withdrawal of chronic i.m. oxytocin treatment, $\mathrm{n}=6$ cows (experiment III).

\begin{tabular}{|c|c|c|c|c|c|c|c|c|}
\hline \multirow{2}{*}{$\begin{array}{l}\text { Experimental day } \\
\text { Parameter }\end{array}$} & \multicolumn{2}{|c|}{ d 0} & \multicolumn{2}{|c|}{ d 19} & \multicolumn{2}{|c|}{ d 20} & \multicolumn{2}{|c|}{ d 21} \\
\hline & Mean & SEM & Mean & SEM & Mean & SEM & Mean & SEM \\
\hline Total milk yield, $\mathrm{kg}$ & $11.88^{\mathrm{a}}$ & 0.65 & $10.94^{b}$ & 0.70 & - & - & $11.97^{\mathrm{a}}$ & 0.69 \\
\hline Spontaneously removed milk, $\mathrm{kg}$ & $10.13^{\mathrm{a}}$ & 0.71 & $7.93^{b}$ & 0.92 & $9.76^{\mathrm{a}}$ & 0.74 & $10.42^{\mathrm{a}}$ & 0.69 \\
\hline Spontaneously removed milk, $\%$ & $85.33^{\mathrm{a}}$ & 3.41 & $71.76^{\mathrm{b}}$ & 4.77 & - & - & $86.89^{\mathrm{a}}$ & 1.22 \\
\hline Residual milk, kg & $1.74^{\mathrm{a}}$ & 0.43 & $3.01^{\mathrm{b}}$ & 0.44 & - & - & $1.55^{\mathrm{a}}$ & 0.13 \\
\hline Residual milk, $\%$ & $14.67^{\mathrm{a}}$ & 0.41 & $28.24^{\mathrm{b}}$ & 4.77 & - & - & $13.12^{\mathrm{a}}$ & 1.22 \\
\hline
\end{tabular}

${ }^{\mathrm{a}, \mathrm{b}}$ Means in the same line without a common superscript letter were significantly different for $(P<0.05)$.

without OT administration were similar to those levels observed during milking before the treatment period. Therefore, reduction of spontaneous milk removal after withdrawal of chronic OT could not be caused by reduced release of endogenous OT.

A further reason for reduced milk ejection after chronic OT treatment could be a reduced sensitivity of OT receptors or reaction to OT of myoepithelial cells in the mammary gland. Chronic premilking $\mathrm{NaCl}$ treatment did not influence mammary gland sensitivity to OT during continuous infusion after long and short milking intervals. In the OT group, the commencement of milk ejection after a long milking interval was similar before and after chronic OT treatment. Chronic OT administration did not change the OT blood concentration required to commence myoepithelial contraction. However, time to reach ejection pressure was prolonged after chronic OT treatment. Intramammary pressure maximum at $3 \mathrm{~h}$ after previous milking, when the udder was relatively empty, tended to be lower after chronic OT treatment, indicating that a higher amount of milk remained unejected. Obviously, myoepithelial contraction stopped at a certain degree of contraction, thus causing incomplete udder emptying. Chronic OT treatment probably affected myoepithelial cells and, after its withdrawal, contractibility of myoepithelial cells at physiological blood OT concentration was reduced.

Normalization of milk removal after chronic OT treatment was fast. Two days after the withdrawal of chronic OT treatment, the amount of residual did not differ when compared to the pretreatment period. Therefore, milk removal during milking $1 \mathrm{~d}$ after withdrawal of OT treatment was also tested. At this milking, spontaneous milk removal already did not differ. Unfortunately, milk removal at the second milking after withdrawal of chronic OT treatment could not be tested because, at the previous milking, cows were i.v. treated with $10 \mathrm{IU}$ of OT. This dose was shown not only to remove residual milk (Bruckmaier, 2003), but also to reduce milk yield at next milking and also slightly reduced milk secretion (Allen, 1990).

\section{CONCLUSIONS}

Intramuscular OT injection (50 IU) caused a long increase of OT blood levels (at least for the $2 \mathrm{~h}$ observed in this study) and prolonged myoepithelial and alveolar contraction. Withdrawal of chronic OT treatment had no negative effect on the release of endogenous OT. It seems that the reduction of spontaneously removed milk was caused by reduced contractibility of myoepithelial cells in the mammary gland at the normal physiological OT concentrations. As a consequence, we stated that chronic OT treatment reduced the sensitivity of the mammary gland to OT.

\section{ACKNOWLEDGMENTS}

We thank T. Dicker for her excellent technical assistance. We also thank A. Knon, C. Fochtmann, D. Tetzlaff, C. Werner-Misof, and S. Schmitz for help during the experiment. This study was supported by Westfalia Landtechnik GmbH, Oelde, Germany.

\section{REFERENCES}

Allen, J. C. 1990. Milk synthesis and secretion rates in cows with milk composition changed by oxytocin. J. Dairy Sci. 73:975-984.

Anderson, R. R., G. A. Hindery, V. Parkash, and C. W. Turner. 1968. Effectiveness of subcutaneously administered oxytocin upon removal of residual milk. J. Dairy Sci. 51:601-605.

Ballou, L. U., J. L. Bleck, G. T. Bleck, and R. D. Bremel. 1993. The effects of daily oxytocin injections before and after milking on milk production, milk plasmin, and milk composition. J. Dairy Sci. 76:1544-1549.

Bruckmaier, R. M. 2003. Chronic oxytocin treatment causes reduced milk ejection in dairy cows. J. Dairy Res. 70:123-126.

Bruckmaier, R. M., and J. W. Blum. 1998. Oxytocin release and milk removal in ruminants. J. Dairy Sci. 81:939-949.

Bruckmaier, R. M., D. Schams, and J. W. Blum. 1992. Aetiology of disturbed milk ejection in parturient primiparous cows. J. Dairy Res. 59:479-489.

Bruckmaier, R. M., D. Schams, and J. W. Blum. 1994. Continuously elevated concentrations of oxytocin are necessary for complete milk removal in dairy cows. J. Dairy Res. 61:323-334.

Deis, R. P. 1971. Inhibition of milk ejection by exogenous oxytocin in lactating rats. J. Dairy Sci. 137:1006-1012.

Donker, J. D., J. H. Koshi, and W. E. Petersen. 1954. The effect of exogenous oxytocin in blocking the normal relationship between endogenous oxytocic substance and the milk ejection phenomenon. Science 119:67. 
Jones, P. M., and I. C. A. F. Robinson. 1982. Differential clearance of nerophysin and neurohypophysial peptides from the cerebrospinal fluid in conscious guinea pigs. Neuroendocrinology 34:297-302.

Knight, C. H. 1994. Short-term oxytocin treatment increases bovine milk yield by enhancing milk removal without any direct action on mammary metabolism. J. Endocrinol. 142:471-473.

Knight, C. H., D. Hirst, and R. J. Dewhurst. 1994. Milk accumulation and distribution in the bovine udder during the interval between milkings. J. Dairy Res. 61:167-177.

Lefcourt, A. M., and R. M. Akers. 1983. Is oxytocin really necessary for efficient milk removal in dairy cows? J. Dairy Sci. 66:2251-2259.

Lollivier, V., D. Rainteau, P.-G. Marnet, S. Letort, S. Delpal, and M. Ollivier-Bousquet. 2001. Early oxytocin effects on secretory events in rabbit and cow mammary cells. Livest. Prod. Sci. 70:180.
Morag, M. 1967. A galactopoetic role for oxytocin in the cow. Life Sci. 6:1513-1518.

Nostrand, S. D., D. M. Galton, H. N. Erb, and D. E. Bauman. 1991. Effects of daily exogenous oxytocin on lactation milk yield and composition J. Dairy Sci. 74:2119-2127.

Petersson, M., P. Alster, T. Lundeberg, and K. Uvnäs-Moberg. 1996. Oxytocin causes a long-term decrease of blood pressure in female and male rats. Physiol. Behav. 60:1311-1315.

Pfeilsticker, H-U., R. M. Bruckmaier, and J. W. Blum. 1995. Interruption of machine milking in dairy cows: Effects on intramammary pressure and milking characteristics. J. Dairy Res. 62:559-566.

SAS Institute. 1999. Version 8 ed. SAS Inst., Inc., Cary, NC.

Schams, D. 1983. Oxytocin determination by radioimmunoassay. III. Improvement to subpicogram sensitivity and application to blood levels in cyclic cattle. Acta Endocrinol. 103:180-183. 